DOI: $10.17976 /$ jpps/2018.02.08

\title{
КОНФЛИКТ МЕЖДУ РОССИЕЙ И ЗАПАДОМ В РОССИЙСКОЙ ПОЛИТИЧЕСКОЙ КАРИКАТУРЕ
}

\author{
С.С. Мельников
}

МЕЛЬНИКОВ Сергей Сергеевич, кандидат социологических наук, ОАНО “Новая школа”. Для связи с автором: xmelnikov@gmail.com

Мельников С.С. Конфликт между Россией и Западом в российской политической карикатуре. Полис. Политические исследования. 2018. № 2. С. 100-114. https://doi.org/10.17976/jpps/2018.02.08

Статья написана в качестве итожащей работу над диссертацией, защищенной в 2017 г. на кафедре социологии МГИМО МИД России.

Статья поступила в редакцию: 09.09.2017. Принята к печати: 25.10.2017

Аннотация. В статье рассматривается инвариантное содержание российских политических карикатур, репрезентация политических процессов в них и - что наиболее существенно - латентных или маскируемых сторон общественнополитической жизни, идентифицируемых в ходе контент-анализа карикатурных изображений. Статус юмора в современном политическом дискурсе заметно вырос из-за медиатизации и виртуализации коммуникационного пространства. При этом в сфере изобразительного юмора, несмотря на появление новых жанров, авторская карикатура по-прежнему обладает наибольшей общественной значимостью. Сюжеты политических карикатур, как и политического юмора в целом, нередко отображают конфликтные эпизоды взаимоотношений между политическим “мы”сообществом, к которой принадлежат художник и аудитория, и антагонистичным “они”-сообществом. Подобные сюжеты характерны и для российской карикатуры, учитывая значительный удельный вес государственной, культурной и национальной принадлежности в коллективной идентичности современных россиян. Как показал сравнительно-исторический анализ, для российской политической карикатуры характерно отображение конфликтов между “мы”-сообществом россиян / русских и "они”-сообществом Запада / представителей конкретных западных обществ. Динамика и степень фокусировки отечественных карикатуристов на данном антагонизме изучаются методом контент-анализа. В ходе исследования было выявлено, что, начиная с перестройки интерес к изображению западных акторов в отечественной политической карикатуре снизился - приоритетными для карикатуристов стали внутрироссийские события и процессы. Привлекательность изображения “мы”группы россиян с течением времени снижается, что говорит о формировании критического отношения к собственным проблемам. При более привлекательной репрезентации “мы”-сообщества россиян западное "они”-сообщество изображается как в целом более выразительное и прогрессивное. Характерное для последних десятилетий перенесение карикатурной противопоставленности “мы”-сообщества и “они” -сообщества из внешнеполитической сферы во внутриполитическую вкупе с полярной идеологической направленностью российских карикатуристов (в том числе и по отношению к Западу) указывает на низкую степень консолидации российского общества.

Ключевые слова: политическая карикатура; политический юмор; идентичность; мы-сообщество; они-сообщество; Россия; Запад; контент-анализ; визуальный образ.

Политические карикатуры, публикуемые в массмедиа и интернете, занимают периферийное место в политическом процессе - как и иные юмористические направления. Тем не менее виртуализация, медиатизация [Соловьев 2002: 7, 9] и визуализация [Шарков 2016] политического пространства придают юмору большую значимость, чем прежде. Каковы его место и роль в современном политическом процессе? 
Немногочисленные исследователи политического юмора относят проявления комического либо к политической культуре [Разуваев 2003: 9], либо к политической коммуникации. Во втором случае юмор может быть рассмотрен как “коммуникационное средство, 'нападающее на' несоответствия, порожденные политическими действиями” [Tsakona, Popa 2011: 6]). Политический юмор служит инструментом формирования новых смыслов, которые генерируются журналистами и представителями смежных сфер деятельности, символически "оформляющих" политические процессы. Данные акторы, как и сами политики, обладают монополией на производство политического дискурса [Bourdieu 2008: 70]. Их сообщения перепозиционируют акторов политического поля и, следовательно, изменяют смысловые реакции общества на политический процесс.

Данным монопольным статусом обладают и художники-карикатуристы, публикующие свои произведения в массмедиа. Согласно исследователям сферы комического, политическая карикатура осмысляет актуальные тематики и задает информационную повестку дня [Sani et al. 2012]. Сегодня визуальный политикоюмористический контент все чаще производится в интернете, генерируя интернет-мемы [Shifman 2014], а карикатуры постепенно сменяются иными жанрами - такими как демотиваторы [Букреева 2011; Фокина 2012]. Тем не менее социетальной значимостью по-прежнему обладают карикатуры, выполненные профессиональными авторами и опубликованные в традиционных СМИ, пусть большинство реципиентов и знакомится с ними в интернете. Характерные примеры - публикация карикатур на пророка Мухаммеда в датской газете “JyllandsPosten", приведшая к массовым протестам мусульман и разгрому датских посольств в ряде исламских стран ${ }^{1}$, расстрел исламистами редакции сатирического журнала "Charlie Hebdo" и последующий общественный резонанс".

В России популярность карикатур в интернете (в том числе первоначально опубликованных в традиционных массмедиа) в последние годы возросла это, в частности, касается изображений, связанных с украинским кризисом [Барабанов 2014]. Вместе с тем данные опросов показывают, что за последние пять-шесть лет количество россиян, интересующихся политикой, стабильно высоко - таковых 44\%, согласно данным Фонда "Общественное мнение" за 2017 г. ${ }^{3}$ Однако корреспондирующего роста политического участия не наблюдается: в последние восемь-десять лет основная часть населения (75-80\%) заявляет о своей неготовности к каким-либо формам политической активности кроме голосования на выборах [Воробьева 2016]. Данный парадокс свидетельствует, что политическая активность граждан реализуется иными способами, в число которых входят создание, потребление и интерпретация юмористических произведений на тему политики.

\section{НАЦИОНАЛЬНО-ГОСУДАРСТВЕННАЯ ПРИНАДЛЕЖНОСТЬ КАК КРАЕУГОЛЬНЫЙ КАМЕНЬ ИДЕНТИЧНОСТИ РОССИЯН}

Карикатура определяется как художественное произведение, в котором в юмористической форме преувеличиваются характерные особенности персонажей

\footnotetext{
${ }^{1}$ Белов Е., Шкуренко О. 2010. 10 ссор неверных с исламом. - Огонек. № 19. С. 25.

2 За час до атаки журнал Charlie Hebdo разместил карикатуру на лидера ИГ. - РИА Новости. 07.01.2015. Доступ: http://ria.ru/world/20150107/1041701896.html\#ixzz3nRgX8nEq (проверено 18.08.2017).

${ }^{3}$ Интерес к событиям в политике. - ФОМ. 29.08.2017. Доступ: http://fom.ru/Politika/13668 (проверено 28.01.2018).
} 
[Москин 2000: 6]. К политическим же карикатурам относятся любые юмористические изображения, на которых изображены люди, стремящиеся к участию во власти / представители власти / политические институции (государства, партии, выборы) / визуализируемые элементы политической культуры. Отечественные исследования, посвященные образам и смыслам политической карикатуры, как правило, акцентируют внимание на событиях или процессах, которым они посвящены, а не на принципах и динамике отображаемого [Барабанов 2016; Букреева 2011; Салатова 2014]. Для зарубежных исследований характерны либо схожие тенденции [Gocek 1998], либо функциональное рассмотрение политических карикатур в отношении их места и роли в массмедиа [Sani 2012].

Однако ответ на любой исследовательский вопрос, связанный с осмыслением политической жизни в карикатурном изображении, требует особого методологического подхода к карикатуре как к сложному вербальновизуальному и юмористическому комплексу. Поэтому для исследователя области политических карикатур представляется важным сформулировать различение, существенное для политической сферы, которое можно наблюдать в конкретной выборке карикатур и на основе которого возможно сформулировать исследовательский вопрос. Таким различением может быть идентификация с собственным государством (“мы”-идентичность) и дифференциация по отношению к иному государству (“они”-идентичность). В политико-философском дискурсе об исключительности государства как основополагающего политического актора, о государстве как “едином лице", осуществляющем "верховную власть”, писал еще Т. Гоббс [Гоббс 2001: 119], а классик социологии XX в. Т. Парсонс указывал, что государство образует ядро политической подсистемы общества [Парсонс 1998: 30]. Исключительная значимость государства для политической жизни подразумевает и значимость идентификации с ним граждан (и, соответственно, дифференциации по отношению к другим государствам).

Отличие имеет прямое отношение к политическому юмору. Так, А.В. Дмитриев в качестве одной из функций политического юмора называет “функцию идентификации, дифференциации и сплоченности” [Дмитриев 1998: 174-177]. Различные направления юмора подчеркивают дистанцию между “мы” и “они” [там же: 271]. Данное подчеркивание не подтверждает уже существующие границы, а само по себе изменяет их, как правило, в сторону еще большего отдаления “они” -сообщества от “мы”-сообщества, образующего аудиторию для юмористического акта или произведения.

Помимо теоретического обоснования значимости различения “мы”идентичности и “они”-идентичности его актуальность обосновывается и тем, что в нашей стране коллективная “мы”-идентичность зачастую определяется через национальную принадлежность (скорее в культурном и политическом, чем в этническом смысле). По данным исследования Института социологии РАН, люди одной национальности - устойчивая самоидентификация для $92 \%$ россиян [Российская идентичность... 2007]. К этому добавляется и высокий уровень гордости за свою страну - по меньшей мере, в течение десяти последних лет примерно 83\% жителей страны стабильно гордятся тем, что живут в России (по данным “Левада-Центра” за 2006 и 2017 гг. $\left.{ }^{4}\right)$.

При такой самоидентификации отношение к “они”-сообществу по национально-государственному признаку довольно критическое: с 1996 по

\footnotetext{
${ }^{4}$ Гордость за страну и народ. - Левада-Центр. 21.12.2017. Доступ: https://www.levada.ru/2017/12/21/17311/ (проверено 18.08.2017).
} 
2017 г. две трети и более россиян утверждают, что у России есть враги - разнообразные "они”-сообщества (наиболее “стабильный” враг - США, в декабре 2017 г. врагом их считали $68 \%$ респондентов) $)^{5}$. Однако отношение к США амбивалентно: в 2017 г. 24\% россиян относились к США хорошо ${ }^{6}$. Сложность и неравнодушие к “они”-сообществам, относящимся к иным государствам и культурам, репрезентируются в различных направлениях юмора, к которым относится и карикатура.

\section{СРАВНИТЕЛЬНО-ИСТОРИЧЕСКИЙ АНАЛИЗ ОБРАЗОВ “МЫ"-СООБЩЕСТВА И “ОНИ"-СООБЩЕСТВА В РОССИЙСКОЙ ПОЛИТИЧЕСКОЙ КАРИКАТУРЕ}

Триггером, способствующим появлению и массовому распространению политической карикатуры, являются драматические перемены общественного устройства. Французский исследователь К. Грет считает, что импульс для появления сатирического рисунка дают революции и войны, благоприятствующие "развитию прессы, отражающей общественное мнение и соответственно карикатурного рисунка"7. Однако революции и войны могут, наоборот, приводить к росту агрессивных острот против внутренних и внешних оппонентов [Kuipers 2008: 374] - и российской политической культуре это оказалось присуще.

Первые российские карикатуры появились в канун 1812 г. Их содержание было направлено против “они”-сообществ - Наполеона и французов, и в течение без малого столетия, до начала XX в., российская политическая карикатура, по большому счету, сводилась к внешнеполитической [Москин 2000: 146]. До Русско-японской войны 1904-1905 гг. в качестве национально-государственных “они”-сообществ в российских карикатурах выступали как конкретные политики и государства, так и обобщенный Запад. Институционализации внутриполитической карикатуры препятствовала цензура.

Знаковым событием для подлинной демократизации политической карикатуры стала революция 1905-1907 гг. Утверждение “'Временных правил’, упразднивших 24 ноября (7 декабря) 1905 г. предварительную цензуру изобразительных материалов в печати" [Голиков, Рыбаченок 2010: 60], создало новую законодательную ситуацию, вследствие которой мишенями карикатуристов вместо привычных зарубежных “они”-сообществ стали император, императорская семья, чиновники, политики-реформаторы [Голиков, Рыбаченок 2010; Москин 2000]. Карикатуры на политический режим создавали многие именитые живописцы, ранее далекие от исследуемого жанра (И.Я. Билибин, Б.М. Кустодиев, В.А. Серов и другие [Голиков, Рыбаченок 2010: 40; Златковский 2002: 31]). Усиление реакции и начало Первой мировой войны способствовали возвращению карикатуры к прежнему характеру репрезентаций: предсказуемо активизировалась политическая карикатура, направленная на внешнего врага [Цыкалов 2012].

\footnotetext{
${ }^{5}$ Враги России. - Левада-Центр. 10.01.2018 Доступ: https://www.levada.ru/2018/01/10/vragi-rossii/ (проверено 28.01.2018).

${ }^{6}$ Отношение к странам и санкциям. - Левада-Центр. 18.12.2017. Доступ: https://www.levada. ru/2017/12/18/otnoshenie-k-stranam-i-sanktsiyam/ (проверено 28.01.2018).

${ }^{7}$ Greth K. 2003. Le dessin de caricature en Russie comme miroir des representations (в переводе В. Богорада и С. Айнутдинова. - Cartoonblues. Доступ: http://www.cartoonblues.com/forum/viewtopic.php?t=4049 (проверено 18.08.2017)).
} 
Февральская революция 1917 г. вновь на короткое время перенесла конфликт между “мы” и “они” во внутреннюю политику: продолжилась публикация карикатур на монархию, распространились антибуржуазные карикатуры, сатирические изображения различных действующих лиц политической арены [там же]. В годы Гражданской войны карикатуры отображали интенции противоборствующих сторон на полях сражений, оттого жесткое антагонистичное отображение "мы"-сообщества и “они”-сообщества было предопределено. Этот характер, а также то, что революция и гражданская война способствовали увеличению вмешательства государства в жизнь людей [Сорокин 2005], определили обязательное наличие “они"-сообщества в публичном дискурсе: после победы над внутренним врагом советская власть жаждала победы над внешним соперником. Политико-карикатурное поле на протяжении всего советского периода жестко ограничивалось цензурой (и проистекающей из нее самоцензурой): конкретные культурные продукты представляли собой часть коммунистической идеологии, которая реализовывалась с помощью партийно-государственных и цензурных органов [Горяева 2009: 7]. Сформировавшийся дискурс отображения “мы”-сообщества и “они”-сообщества в карикатурах позволяет сформулировать гипотезу эмпирического исследования: культурно-национальная идентичность персонажей, относящихся к российскому (или советскому - в зависимости от исторического периода) народу представлена аудитории привлекательной, а соответствующая идентичность западных обществ - преимущественно непривлекательной.

Великая Отечественная война предсказуемо усилила поляризацию “мы"-сообщества и "они”-сообщества (нацистская Германия и ее союзники) - роль карикатуры в патриотической мобилизации советского народа была высока, что осознавали и власти нацистской Германии [Казаневский 2004: 141]. Условия военного времени подталкивали карикатуристов к репрезентации именно физического уничтожения представителей “они”-сообщества - так, на карикатуре В. Дени времен Великой Отечественной фашист насильственно “подавляется" красноармейцем, что следует даже из подписей к карикатурам (например, “Ходил немец 'в гости' - скоро будет на погосте" [Иоффе 1971: 26]). Апогеем данного этапа стал Нюрнбергский процесс, в котором принимали участие художники Борис Ефимов и Кукрыниксы. Согласно советским искусствоведам, они с “беспощадным реализмом” раскрывали “внутреннюю природу, звериную сущность обанкротившихся авантюристов” (см. рис. 1) [там же: 175]).

На этапе 1964-1985 гг. советская карикатура перестала быть монолитом в идеологическом смысле, разделившись на три потока. Заключительным этапом хрущевской эпохи датируется рождение совершенно новой карикатуры, называемой “юмором молодых” [Златковский 2002]. Карикатура нового поколения художников стала задавать вечные вопросы - о “личности и ее окружении, смысле жизни и смерти". Вкупе с философской неформальной карикатурой в СССР возник и андеграундный соц-арт.

\footnotetext{
${ }^{8}$ Greth K. 2003. Le dessin de caricature en Russie comme miroir des représentations (в переводе В. Богорада и С. Айнутдинова. - Cartoonblues. Доступ: http://www.cartoonblues.com/forum/viewtopic.php?t=4049 (проверено 18.08.2017)).
} 
Кукрыниксы. Нюрнбергский процесс 9

Kukryniksy. The Nuremberg Trials

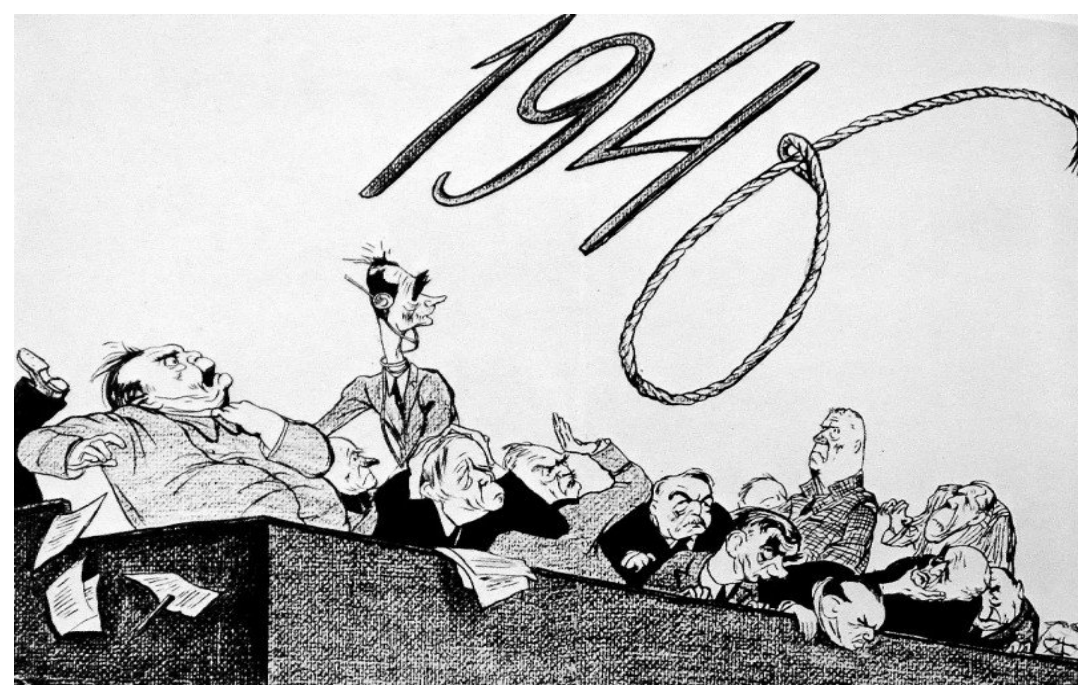

Стоит отметить художника В. Сысоева, заключенного в тюрьму и позднее эмигрировавшего в Германию: тот недвусмысленно демонстрировал, как в Советском Союзе подавляют свободу мысли и слова (в частности, изображая людей с головами в виде закрытой коробки).

\section{В. Сысоев. Из серии "Болваны"10}

V. Sysoev. From the series "Fools"

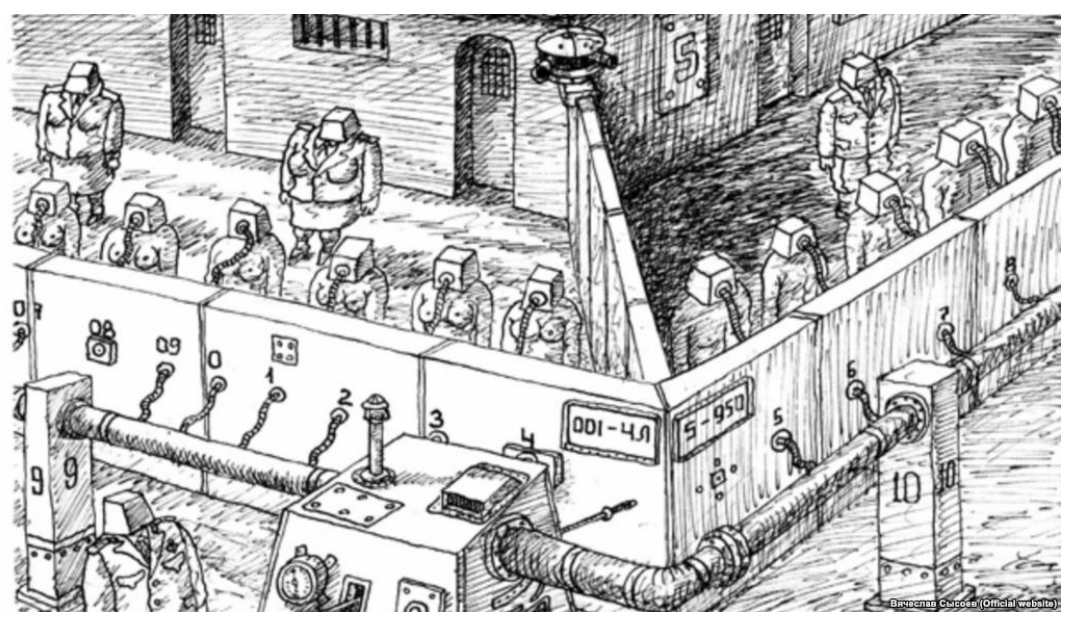

\footnotetext{
${ }^{9}$ Викулова Л. Знак четырех. Трое в лодке, не считая Кукрыниксы. - Moiarussia.ru. Доступ: https:// moiarussia.ru/znak-chetyreh-troe-v-lodke-ne-schitaya-kukryniksy (проверено 18.08.2017).

${ }^{10}$ Померанцев И. Воспоминания о заключении. - Радио Свобода. 19.07.2013. Доступ: https://www. svoboda.org/a/25049016.html (проверено 18.01.2018).
} 
На рис. 2 изображена карикатура из серии “Болваны”, отношение к которой правоохранительных органов сам художник описывал так: “Да ничего я такого и не рисую. Ну, подумаешь, болваны какие-то... Так они же думают, что это я их рисую. И решили они мне устроить веселую жизнь” [Сысоев 1983: 70]. Тем не менее в СМИ по-прежнему существовал жесткий идеологический диктат, поэтому карикатура по преимуществу наследовала той, что распространялась с 1917 г.

В перестройку начинается новый этап в истории политической карикатуры России. Была провозглашена свобода слова, исчезла директивная политическая карикатура (а значит и навязываемое “сверху” деление на “мы”-сообщества и "они”-сообщества), появилось разнообразие “мы"-сообществ и “они”-сообществ. Политический плюрализм 1990-х г. закономерно привел к еще большей хаотизации отображения “мы”-сообществ и “они”-сообществ в карикатурах. Обозначение представителей той или иной общности как “своих” либо “чужих” стало во многом зависеть от издателя и владельца массмедиа [Златковский 2002: 77].

К 2000-2010-м годам формируются два более-менее очерченных направления карикатур в массмедиа с противоположными представлениями о “мы"сообществах и “они”-сообществах. Первое из них можно назвать традиционалистски-державническим, в котором роль “мы”-сообщества выполняют российская власть, обобщенный российский народ; “они”-сообществами являются представители Запада и дружественных им международных сил, российская либеральная оппозиция (Г. Животов - газета “Завтра”, В. Подвицкий - МИА “Россия сегодня”). Правящие структуры в определенной степени поддерживают распространение указанных диспозиций в карикатурных изображениях (так, “Россия сегодня" государственное информационное агентство), однако не определяют содержание изображений, что было характерно для советского периода.

Второе направление можно назвать либерально-негативистским. "Мы”сообщества здесь представляют (хотя зачастую лишь подразумеваются) российская либеральная оппозиция и условно демократические силы мира, а к “они”-сообществам относятся российская государственная власть и условно антидемократические силы мира (А. Меринов - "Московский комсомолец", С. Елкин - Радио "Свобода”, "Deutsche Welle”). Указанные направления вполне соответствуют широко признаваемому делению российского политического поля на “этатистов-державников” и “либералов” [Горшков 2015: 17], “традиционалистское большинство” и “вестернизированное меньшинство” [Лукин 2014: 162].

\section{КОНТЕНТ-АНАЛИЗ ПРИВЛЕКАТЕЛЬНОСТИ ВИЗУАЛЬНЫХ ОБРАЗОВ РОССИЙСКИХ “МЫ”-СООБЩЕСТВ И ЗАПАДНЫХ “ОНИ”-СООБЩЕСТВ}

Исторический анализ демонстрирует, что в отечественной истории господствовала политическая карикатура, отображающая антагонизм между “мы”-сообществами россиян / русских и “они”-сообществами Запада / представителей конкретных западных обществ, в котором “мы”-сообщество оказывается привлекательнее “они”-сообщества. Однако вывод требует верификации более формализованными и научно обоснованными методами. Для эмпирического исследования политических карикатур необходимым представляется обращение к методу контент-анализа.

Контент-анализ предполагает рассмотрение карикатур как текста, что соответствует общенаучному подходу: значением обладают не только вербальные, но и визуальные материалы [Bell 2001: 15]. Также карикатура зачастую 
содержит подтекст либо контекст, который не всегда может быть обнаружен реципиентом и не всегда эксплицирован для самого художника или издателя, но может быть определен в ходе глубинной исследовательской интерпретации. Американский историк и искусствовед Э. Панофский в связи с этим выделяет несколько уровней анализа визуального образа в конкретном художественном изображении (см. табл. 1) [Панофский 2009: 43].

Таблица 1 ( Table 1)

Программа контент-анализа в соотнесении с уровнями анализа визуального образа

Content Analysis Program in Reference with the Levels of Analysis of Visual Image

\begin{tabular}{|c|c|c|}
\hline $\begin{array}{c}\text { Уровни } \\
\text { анализа } \\
\text { визуального } \\
\text { образа }\end{array}$ & $\begin{array}{c}\text { Концептуальная часть } \\
\text { контент-анализа образов “мы”- } \\
\text { сообщества и “они”-сообщества } \\
\text { в политических карикатурах }\end{array}$ & $\begin{array}{c}\text { Операциональная часть } \\
\text { контент-анализа образов “мы”- } \\
\text { сообщества и “они”-сообщества } \\
\text { в политических карикатурах }\end{array}$ \\
\hline $\begin{array}{l}\text { 1а. Первичное } \\
\text { фактическое } \\
\text { содержание }\end{array}$ & $\begin{array}{l}\text { Идентификация принадлежности } \\
\text { персонажа к мы”-сообществу или } \\
\text { “они”-сообществу }\end{array}$ & $\begin{array}{l}\text { Фиксация персонажа в качестве } \\
\text { единицы анализа для присвоения } \\
\text { ему значений по следующим ниже } \\
\text { категориям анализа }\end{array}$ \\
\hline \multirow{2}{*}{$\begin{array}{l}\text { 1б. Первичное } \\
\text { экспрессивное } \\
\text { содержание }\end{array}$} & $\begin{array}{l}\text { Определение первой } \\
\text { категории анализа - внешней } \\
\text { привлекательности (биологической } \\
\text { внешности и явного поведения). }\end{array}$ & $\begin{array}{l}\text { Присвоение каждой единице } \\
\text { анализа (персонажу) значения по } \\
\text { трехчленной номинальной шкале } \\
(0,1,2) \text { в зависимости от уровня } \\
\text { внешней привлекательности. Чем } \\
\text { больше значение, тем она выше. }\end{array}$ \\
\hline & $\begin{array}{l}\text { Определение второй категории } \\
\text { анализа - презентационной } \\
\text { привлекательности } \\
\text { (сконструированной внешности } \\
\text { персонажа - одежды и манер). }\end{array}$ & $\begin{array}{l}\text { Присвоение каждой единице } \\
\text { анализа значения по } \\
\text { трехчленной номинальной } \\
\text { шкале }(0,1,2) \text { в зависимости } \\
\text { от уровня презентационной } \\
\text { привлекательности. Чем больше } \\
\text { значение, тем она выше. }\end{array}$ \\
\hline $\begin{array}{l}\text { 2. Вторичное } \\
\text { (условное) } \\
\text { содержание }\end{array}$ & $\begin{array}{l}\text { Определение третьей } \\
\text { категории анализа - сюжетной } \\
\text { привлекательности (наличие } \\
\text { либо отсутствие насмешки } \\
\text { над персонажем). }\end{array}$ & $\begin{array}{l}\text { Присвоение каждой единице } \\
\text { анализа значения по } \\
\text { трехчленной номинальной } \\
\text { шкале }(0,1,2) \text { в зависимости } \\
\text { от степени насмешки. Чем } \\
\text { меньше степень насмешки, тем } \\
\text { выше привлекательность. }\end{array}$ \\
\hline $\begin{array}{l}\text { 3. Внутреннее } \\
\text { содержание } \\
\text { (значение) }\end{array}$ & $\begin{array}{l}\text { Интерпретация соотнощения } \\
\text { привлекательности" “ы”- } \\
\text { сообщества и “они”-сообщества } \\
\text { как за весь исследуемый } \\
\text { период, так и за конкретные } \\
\text { временные этапы. }\end{array}$ & $\begin{array}{l}\text { Определение суммарной } \\
\text { привлекательности для } \\
\text { каждого персонажа } \\
\text { и совокупной привлекательности } \\
\text { персонажей. Возможность } \\
\text { сопоставления персонажей по } \\
\text { различным критериям. }\end{array}$ \\
\hline
\end{tabular}

Под первичным содержанием понимается восприятие формы как таковой, а также таких экспрессивных свойств как "печальный характер позы или жеста” [там же: 30]. Вторичное содержание раскрывает темы и понятия, выраженные в образах, что предполагает раскрытие мотивов, действующих в конкретной сцене изображения. Внутреннее же содержание предполагает установление символического значения образа, постигаемое через выявление основополагающих принципов, характерных для “определенной нации, эпохи, общественного слоя, религиозных или философских убеждений” [там же: 32], которые художник невольно репрезентирует в отдельном произведении.

Данную схему возможно адаптировать к анализу политических карикатур на предмет привлекательности "мы”-сообществ и “они”-сообществ. Ниже в табличном виде представлена программа контент-анализа (без выделения 
генеральной и выборочной совокупности). Каждому уровню анализа изображения соответствуют конкретные концептуальные шаги контент-анализа образов “мы”-сообщества и “они”-сообщества в политических карикатурах и операционализация данных шагов.

Из указанной ранее основной гипотезы исследования исходит несколько гипотез-следствий:

1) При смене исторических этапов число карикатур, изображающих представителей “мы”-сообществ, стабильно невысокое, а число карикатур, изображающих представителей “они”-сообществ, стабильно высокое (они наиболее предпочтительны);

2) С течением времени привлекательность “мы”-сообществ, вследствие более критического отношения к ним, сокращается, а привлекательность “они”-сообществ увеличивается;

3) Представители “мы”-сообщества привлекательнее представителей “они” -сообщества по всем обозначенным категориям.

В генеральную совокупность исследовательской части, в силу затрудненности доступа к газетам и журналам XIX и начала XX вв., включены карикатуры, опубликованные в российских печатных изданиях, начиная с 1921 г. Из-за неравномерности представленности карикатур в печатных массмедиа и неизбежной субъективности при отборе изданий предпочтение было отдано целевой выборке, которая является "качественно представительной для целей анализа" [Темницкий 2003: 74]. Исследовательские стандарты требуют, чтобы в рамках целевой выборки “единицы наблюдения скорее представляли предполагаемые полярные случаи в рамках генеральной совокупности, а не типичные” [там же: 75].

Разнообразие единиц наблюдения обеспечивалось посредством контроля двух параметров: 1) временного этапа: указанный период был разделен на 10 этапов, совпадающих со сменой основных властных нарративов - 1921-1928 (от введения НЭП до начала коллективизации и первой пятилетки); 1928-1941 (до начала Великой Отечественной войны); 1941-1945 (до окончания войны); 1945-1953 (до смерти Сталина); 1953-1964 (хрущевская “оттепель”); 1964-1985 (“застой”); 1985-1991 (перестройка); 1991-2000 (Россия при Борисе Ельцине); 2000-2008 (первые два президентских срока Владимира Путина); 2008-2016 (от президентства Дмитрия Медведева до продолжающегося третьего срока Путина); 2) выбора конкретного издания: в выборку включались карикатуры из различных популярных (“национальных", “общесоюзных”) печатных СМИ.

Достаточным для проверки гипотезы исследования представлялся анализ карикатур, равномерно распределенных по историческим этапам. Источником отбора карикатур служили следующие массмедиа (на конкретном этапе одно СМИ не использовалось более двух раз): “Правда", "Известия", “Комсомольская правда”, “Труд”, “Крокодил”, “Литературная газета”, “Московский комсомолец”, “Завтра", “Коммерсанть”.

Политические карикатуры отбирались при наличии в них соответствующих объектов, явных или контекстуальных (представитель государственной власти либо человек, стремящийся к ее обретению, либо политический институт). В каждом изображении идентифицировался по крайней мере один представитель исследуемых “мы”-сообществ или “они”-сообществ, но зачастую в одном изображении были обнаружены представители обоих сообществ.

На уровне первичного фактического содержания изображений, в соответствии с первой гипотезой-следствием, был получен ответ на вопрос о по- 
стоянстве соотношений “мы”-сообществ и “они”-сообществ в российской карикатуре. Данная гипотеза была опровергнута: в ходе институционализации советской общественной системы выросло представительство “мы”-сообществ в отечественной карикатуре и снизилось число западных лиц и институтов. Из рис. 3 следует, что доля “они”-сообществ в карикатурах 1920-х годов была стопроцентной, однако постепенно падала и на этапе перестройки сократилась до минимума. Число же карикатур, в которых отображаются “мы”-сообщества, резко увеличивается, начиная с этого периода. Можно сделать вывод о росте своеобразной общественной самоиронии, о готовности интерпретировать в юмористическом ключе собственные внутриполитические сложности.

Рисунок 3 (Figure 3)

Распространенность карикатур,

изображающих "мы"- и “они"-сообщества, с течением времени

Prevalence of Cartoons Depicting In-Group and Out-Group Over Time

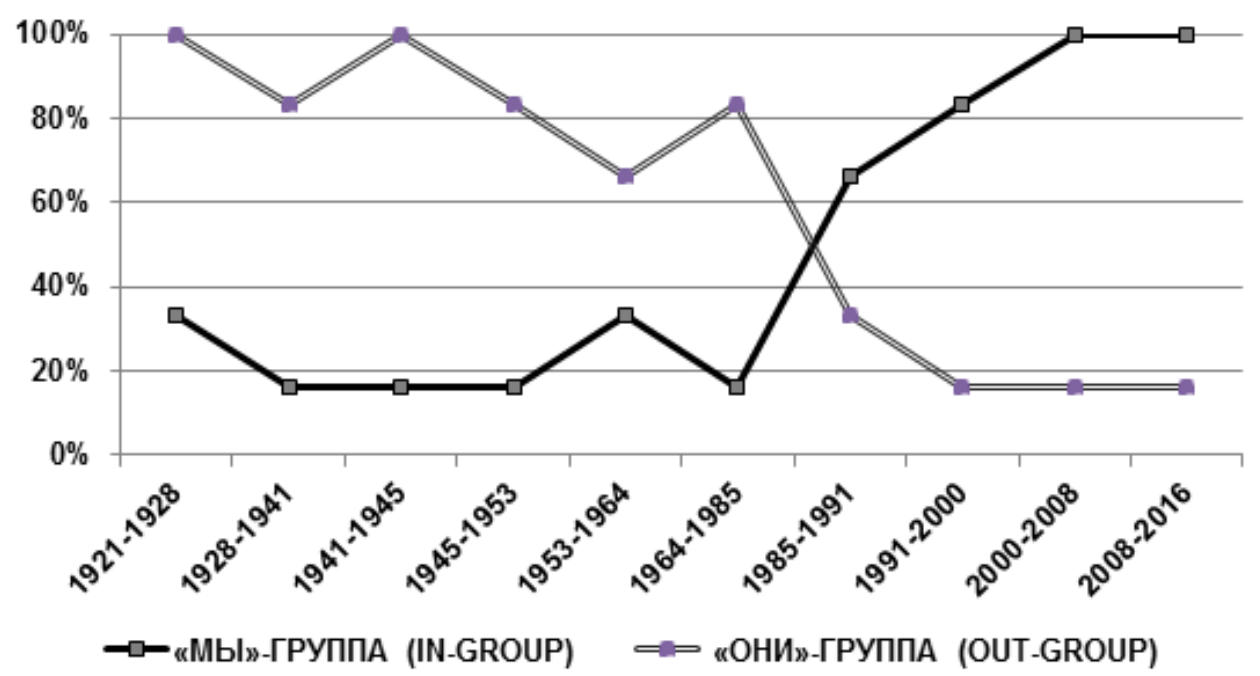

Следующая гипотеза-следствие - о том, что с течением времени привлекательность “мы”-сообществ, вследствие более критического отношения к ней, сокращается, а привлекательность “они”-сообществ увеличивается - подтверждена частично (см. рис. 4). Действительно, отношение к “мы” сообществам на постсоветской карикатуре меняется в сторону ухудшения, она становится менее привлекательной. Привлекательность же “они”-сообществ стабильно невысока. Вместе с тем о релевантности данных применительно к постсоветским карикатурам говорить вряд ли можно, так как на отобранных карикатурах число представителей “они”-сообществ минимально, их необходимо изучать целенаправленно.

Третья гипотеза - о том, что представители “мы” -сообществ привлекательнее представителей “они”-сообществ по всем категориям, также подтверждена лишь частично. Различие средних значений привлекательности “мы”-сообществ и “они” -сообществ не столь велико, особенно учитывая ангажированность советской карикатуры против “они”-сообществ. Общие невысокие значения можно объяснить отчасти тем, что жанр карикатуры как таковой предполагает отображение несообразностей, а не положительных черт. 


\section{Привлекательность “мы”- и “они”-сообществ с течением времени Attractiveness of In-Group and Out-Group Over Time}

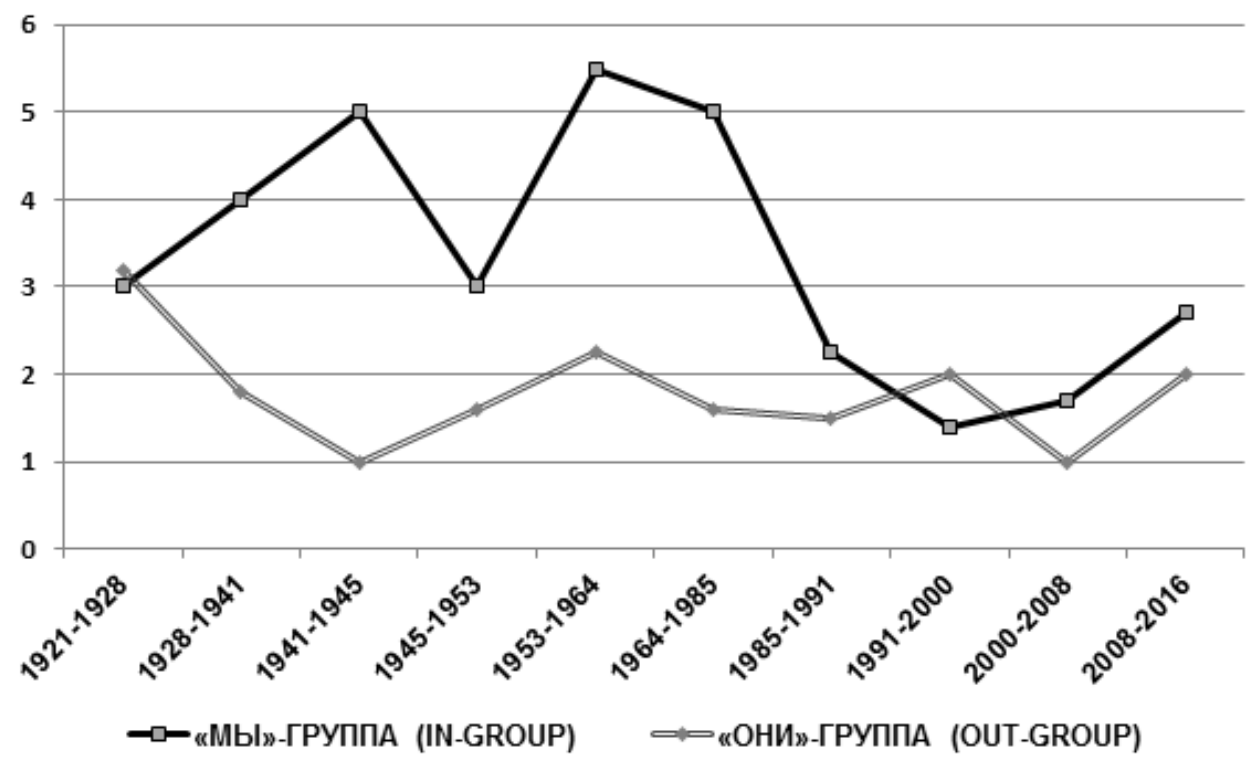

Дифференцированные результаты демонстрируют, что на протяжении всего рассматриваемого периода презентационная привлекательность “они”сообщество (внешности и манер) превосходила соответствуюшую привлекательность "мы” -сообщества. Внешне же “мы”-сообщества в целом изображались как более привлекательные. Различие средних значений привлекательности “мы”-сообществ и “они”-сообществ отображены в табл. 2.

таблица 2(Table 2)

Средние значения привлекательности "мы"- и “они"-сообществ Average Meanings of the Attractiveness of In-Group and Out-Group

\begin{tabular}{|l|l|c|c|}
\hline \multicolumn{2}{|c|}{ Параметры значений привлекательности } & \multicolumn{2}{c|}{$\begin{array}{c}\text { Значения } \\
\text { привлекательности }\end{array}$} \\
\cline { 3 - 4 } \multicolumn{2}{|c|}{$\begin{array}{c}\text { “Мы”- } \\
\text { сообщества }\end{array}$} & $\begin{array}{c}\text { “Они”- } \\
\text { сообщества }\end{array}$ \\
\hline \multirow{2}{*}{ Общая сумма } & 76 & 67 \\
\hline \multirow{3}{*}{$\begin{array}{l}\text { Среднее } \\
\text { арифметическое } \\
\text { значений... }\end{array}$} & $\ldots$...ривлекательности & 2,6 & 1,9 \\
\cline { 2 - 4 } & $\ldots$..презентей привлекательности & 0,8 & 0,3 \\
\cline { 2 - 4 } & $\ldots$..сюжетной привлекательности & 1,1 & 1,3 \\
\hline
\end{tabular}

Таким образом, на уровне первичного экспрессивного и вторичного (условного) содержания основная гипотеза подтверждена частично: комбинированная привлекательность отечественных персонажей выше, но она сравнительно невелика, а привлекательность образов западных институтов и лиц несколько превзошла гипотетический уровень. 


\section{ОСНОВНЫЕ ВЫВОДЫ}

Образы представителей западных обществ в российской политической карикатуре оказались в целом менее симпатичны, чем образы россиян, - и в этом отношении основная гипотеза исследования не была опровергнута, однако разница между средними значениями их совокупной привлекательности оказалась невелика. Более того, привлекательность “мы”-сообществ постепенно снижается.

Карикатуристы различными эстетическими средствами предлагали более рельефное и насыщенное отображение "наших оппонентов", чем отображение отечественных политических лиц и институтов. В этом высока роль презентационной привлекательности: классический либо просто аккуратный стиль одежды персонажа в визуальном отношении оставляет у реципиента хорошее впечатление. Выразительность и насыщенность в отображении западных “они”-сообществ при общем критическом отношении к ним говорит об особом сочетании качеств, характерных для советского периода: зависти к западному уровню организации общественной жизни и специфического чувства духовного превосходства России перед меркантильной цивилизованностью “передовых народов”.

Особенность постсоветского этапа развития политической карикатуры в том, что, хотя “мы”-сообщество стало изображаться значительно чаще, противопоставление между ним и “они”-сообществом не утрачивает своей значимости. Дифференцированность современной прессы (электронно-сетевой в том числе) привела к некоторому разнообразию в подходах к указанной тематике. На современной карикатуре появилось отображение противоречий между облеченными властью акторами и “народом", т.е. "мы” -сообществом с точки зрения художника. С одной стороны, художественная рефлексия над происходящим в государстве граждански ориентирована в большей степени, нежели рефлексия над смыслами внешнеполитических химер (которая, надо заметить, до конца еще не утрачена). С другой стороны, гипертрофированная драматичность отечественной карикатуры и неизменная противопоставленность одних персонажей другим характерны для всех исследуемых этапов и опосредованным образом олицетворяют низкую степень консолидации российского общества, несмотря на формально высокий уровень национальной гордости.

$$
* * *
$$

Контент-анализ политических карикатур, связанный с выявлением латентной структуры содержания изображений, позволил выйти на иной уровень обобщения по сравнению со сравнительно-историческим анализом, что говорит о перспективе данного метода для формулировки новых предварительных выводов и новых гипотез. Вне всякого сомнения, оптимальным методическим выбором для последующего изучения привлекательности “мы”-сообщества и “они” -сообщества на примере карикатур стало бы проведение комплексного исследования с помощью различных методов на примере одной выборочной совокупности. Например, метода фокус-групп - для выявления восприятия различными группами населения степени объективности и актуальности отражения политической ситуации в карикатурах.

Барабанов О.Н. 2014. После Крыма: визуальный гротеск российских социальных медиа - Россия в глобальной политике. № 3. Доступ: http://globalaffairs.ru/ukraine_crysis/ Posle-Kryma-vizualnyi-grotesk-rossiiskikh-sotcialnykh-media-16683 (проверено 18.08.2017).

Букреева О.В. 2011. Образ российской власти и политических лидеров в концептуальном пространстве демотивационных постеров. - Полис. Политические исследования. 2011. № 5. С. 117-122. Доступ: http://www.politstudies.ru/article/4467 (проверено 18.01.2018). 
Воробьева И.В. 2016. Противоречия и парадоксы политических ориентаций в структуре жизненного мира россиян. - Социологические исследования. № 1. С. 17-26.

Гоббс Т. 2001. Левиафан. М.: Мысль. 478 с.

Голиков А.Г., Рыбаченок И.С. 2010. Смех - дело серьезное. Россия и мир на рубеже $X I X-X X$ веков в политической карикатуре. М.: Институт российской истории РАН. 328 с.

Горшков М.К. 2015. О влиянии неэкономических факторов на социально-экономическое развитие общества. - Гуманитарий Юга России. № 1. С. 15-25.

Горяева Т.М. 2009. Политическая цензура в СССР. 1917-1991 гг. М.: РОССПЭН. 407 с. Дмитриев А.В. 1998. Социология политического юмора: очерки. М.: РОССПЭН. 332 с.

Златковский М. 2002. “Юмор молодых": из истории карикатуры в России 1953-2000 годы. - Феноменология смеха. Карикатура, пародия, гротеск в современной культуре. М.: Российский институт культурологии. С. 28-83.

Иоффе М. 1971. Десять очерков о художниках-сатириках. М.: Сов. Художник. 296 с.

Казаневский В.А. 2004. Искусство современной карикатуры. Киев: Альтерпрес. 152 с.

Лукин А.В. 2014. Шовинизм или хаос: порочный выбор для России. - Полис. Политические исследования. № 3. С. 159-171. https://doi.org/10.17976/jpps/2014.03.10

Москин Д.Н. 2000. Краткая энциклопедия карикатуры. Петрозаводск: ПетроПресс. 208 с.

Панофский Э. 2009. Этюды по иконологии: гуманистические темы в искусстве Возрождения. СПб.: Азбука-Классика. 432 с.

Парсонс Т. 1998. Система современных обществ. М.: Аспект Пресс. 270 с.

Разуваев В.В. 2003. Политический смех в современной России. М.: ГУ-ВШЭ. 262 с.

Российская идентичность в социологическом измерении (аналитический доклад). 2007. - Институт социологии РАН, Представительство Фонда им. Ф. Эберта в РФ. Доступ: http://www.isras.ru/analytical_report_Ident.html (проверено 18.08.2017).

Салатова Л.М. 2014. Стереотипные образы мирового кризиса в российских и американских графических моделях. - Вестник Челябинского государственного универсиmema. № 10. С. 110-115.

Соловьев А.И. 2002. Политическая коммуникация: к проблеме теоретической идентификации. - Полис. Политические исследования. № 3. С. 5-18. https://doi.org/10.17976/ jpps/2002.03.02

Сорокин П.А. 2005. Социология революции. М.: РОССПЭН. 704 с.

Сысоев В.В. 1983. Ходите тихо, говорите тихо. Париж - Нью-Йорк: Третья волна. 98 с.

Темницкий А.Л. 2003. Учебное исследование по эмпирической социологии. М.: МГИМО МИД России. 250 с.

Фокина М.А. 2012. Демотиваторы в России и США: новые жанры интернет-коммуникации в глобализирующемся мире. - Вестник Нижегородского государственного лингвистического университета им. Н.А. Добролюбова. № 20. С. 74-85.

Цыкалов Д.Е. 2012. Карикатура как орудие пропаганды в период Первой мировой войны. - Вестник ВолГУ. Серия 4. № 1. С. 85-90. http://dx.doi.org/10.15688/jvolsu4.2012.1.12

Шарков Ф.И. 2016. Визуализация политического медиапространства. - Полис. Политические исследования. № 5. С. 97-107. https://doi.org/10.17976/jpps/2016.05.08

Bell P. 2001. Content Analysis of Visual Images. - The Handbook of Visual Analysis. Ed by T. van Leeuwen, C. Jewitt. London: SAGE Publications Ltd. P. 10-35.

Bourdieu P. 2008. Giving Voice to the Voiceless. - P. Bourdieu. Political Interventions: Social Science and Political Action. London: Verso. P. 70-78.

Gocek F.M. 1998. Political Cartoons in the Middle East. Princeton: Markus Wiener Publishers. $155 \mathrm{p}$.

Kuipers G. 2008. Sociology of Humour. - The Primer of Humour Research. Ed. by V. Raskin. Berlin, New York: Mouton de Gruyter. P. 366-423. 
Sani I., Abdullah M.H., Abdullah F.S., Ali A.M. 2012. Political Cartoons as a Vehicle of Setting Agenda: the Newspaper Example. - Asian Social Science. Vol. 8. No. 6. http:// dx.doi.org/10.5539/ass.v8n6p156

Shifman L. 2014. Memes in Digital Culture. Cambridge, MA: MIT Press. 199 p.

Tsakona V., Popa D.E. 2011. Studies in Political Humour: In Between Political Critique and Public Entertainment. Amsterdam/Philadelphia: John Benjamins Publishing Company. 290 p.

DOI: $10.17976 / \mathrm{jpps} / 2018.02 .08$

\title{
IN-GROUP AND OUT-GROUP IN RUSSIAN POLITICAL CARTOONS: RESEARCH OF THE LATENT MEANINGS OF NARRATIVE CONFLICT BETWEEN RUSSIA AND THE WEST
}

\author{
S.S. Melnikov ${ }^{1}$ \\ ${ }^{1}$ Autonomous non-profit educational organization "New School”. Moscow, Russia
}

MELNIKOV Sergei Sergeevich, Cand. Sci. (Soc.), autonomous non-profit educational organization "New School". Email: xmelnikov@gmail.com

Melnikov S.S. In-Group and Out-Group in Russian Political Cartoons: Research of the Latent Meanings of Narrative Conflict between Russia and the West. - Polis. Political Studies. 2018. No. 2. P. 100-114. (In Russ.) https://doi. org/10.17976/jpps/2018.02.08

The article summarizes the dissertation defended in 2017 at the Department of Sociology of MGIMO-University.

Received: 04.09.2017. Accepted: 25.10.2017

\begin{abstract}
The article examines the invariant contents of Russian political cartoons, the representation of actual political processes in it and, most significantly, the implicit or masked aspects of sociopolitical life identified via content analysis of the caricature image. The author claims that the virtualization of politics has given humor an additional significance for contemporary political discourse. Despite the emergence of new genres, professional cartoons in the media are still the static-visual humor direction most in demand. Plots of political cartoons as well as of political humor in general often reflect conflict episodes of the relationship between in-group (for the artist and audience) and out-group. This is also true for the Russian cartoons, given the relatively high importance of state, cultural and national identity for Russian collective identity. As shown by the comparative-historical analysis, the representation of conflicts between Russians as in-group and the West / representatives of Western societies as out-group is typical for Russian cartoons. The profound meanings of the reflection of Russian cartoonists over this antagonism and the dynamics of the concentration on it are studied by the method of content analysis. This study revealed that since the "perestroika" time the interest to represent Western political actors in cartoons has decreased - the domestic events and processes became a priority. The attractiveness of the in-group representation declines over time, which indicates a more critical attitude to the Russian internal problems. With a greater overall attractiveness of Russian in-group, it is important to note that, as a result of content analysis, out-group representatives are shown as more impressive and presentable. The transfer of the in-group and the out-group antagonism from the foreign policy field to the internal policy field which is characteristic of the last decades, coupled with the polar ideological orientation of contemporary Russian cartoonists (including the attitude toward the West), indicates a low consolidation of Russian society.
\end{abstract}

Keywords: political cartoon; political humor; identity; in-group; out-group; Russia; the West; content analysis; visual image.

\section{References}

Barabanov O.N. After Crimea: Visual Grotesque of the Russian Social Media. - Russia in Global Affairs. 2014. No. 3 (In Russ.). URL: http://globalaffairs.ru/ukraine_crysis/Posle-Kryma-vizualnyi-groteskrossiiskikh-sotcialnykh-media-16683 (accessed 18.08.2017).

Bell P. Content Analysis of Visual Images. - The Handbook of Visual Analysis. Ed. by T. van Leeuwen, C. Jewitt. London: SAGE Publications Ltd. 2001. P. 10-35.

Bourdieu P. Giving Voice to the Voiceless. - P. Bourdieu. Political Interventions: Social Science and Political Action. London: Verso. 2008. P. 70-78. 
Bukreeva O.V. Image of the Russian Power and of Political Leaders in the Conceptual Space of Demotivation Posters. - Polis. Political Studies. 2011. No. 5. P. 117-122 (In Russ.) URL: http://www.politstudies.ru/en/article/4467

Dmitriev A.V. Sotsiologiya politicheskogo yumora: ocherki [Sociology of Political Humor: Essays]. Moscow: ROSSPEN. 1998. 332 p. (In Russ.)

Fokina M.A. Demotivators in Russia and in the USA: an Attempt at Comparative Analysis. - VESTNIK of Nizhny Novgorod Linguistics University. 2012. No. 20. P. 74-85. (In Russ.)

Gocek F.M. Political Cartoons in the Middle East. Princeton: Markus Wiener Publishers. 1998. 155 p.

Golikov A.G., Rybachenok I.S. Smekh - Delo Ser'eznoe. Rossiya I Mir Na Rubezhe XIX-XX Vekov $V$ Politicheskoi Karikature [Laughter Is A Serious Matter. Russia and The World At The Turn Of The 19th And 20th Century]. Moscow: Institute of Russian History RAS. 2010. 328 p. (In Russ.)

Gorshkov M.K. On the Influence of Non-Economic Factors on the Socio-Economic Development of the Society. - Gumanitarii Yuga Rossii. 2015. No. 1. P. 15-25. (In Russ.)

Goryaeva T.M. Politicheskaya Tsenzura v SSSR. 1917-1991 gg. [Political Censorship in the USSR. 1917-1991]. Moscow ROSSPEN. 407 p. (In Russ.)

Hobbes T. Leviathan. (Russ. ed.: Hobbes T. Leviafan. Moscow: Mysl'. 2001. 478 p.)

Ioffe M. Desyat' Ocherkov O Khudozhnikakh-Satirikakh [Ten Essays on Satirical Artists]. Moscow: Sov. Khudozhnik. 1971. 296 p. (In Russ.)

Kazanevskii V.A. Iskusstvo Sovremennoi Karikatury [The Art of Modern Cartoon]. Kiev: Al'terpress. 2004. 152 p. (In Russ.)

Kuipers G. Sociology of Humour. - The Primer of Humour Research. Ed. By V. Raskin. Berlin, New York: Mouton de Gruyter. 2008. P. 366-423.

Lukin A.V. Chauvinism or Chaos: Russia’s Unpalatable Choice. - Polis. Political Studies. 2014. No. 3. P. 159-171. (In Russ.) https://doi.org/10.17976/jpps/2014.03.10

Moskin D.N Kratkaya entsiklopediya karikatury [Brief Encyclopedia of Cartoon]. Petrozavodsk: PetroPress. 2000. 208 p. (In Russ.)

Panofsky E. Studies in Iconology: Humanist Themes in the Art of the Rennaissance. (Russ. ed.: Panofskiy E. Etyudy po ikonologii: gumanisticheskie temy v iskusstve Vozrozhdeniya. St. Petersburg: Azbuka-Klassika. 2009. 432 p.)

Parsons T. System of Modern Societies. (Russ. ed.: Parsons T. Sistema sovremennykh obshchestv. Moscow: Aspect Press. 1998. 270 p.)

Razuvaev V.V. Politicheskii Smekh V Sovremennoi Rossii [Political Laughter in Contemporary Russia]. Moscow: The Higher School of Economics Publishing House. 2003. 262 p. (In Russ.)

Rossiiskaya Identichnost'v Sotsiologicheskom Izmerenii (Analiticheskii Doklad) [Russian Identity in Sociological Dimension (analytical report)]. - Institute of Sociology or RAS, Friedrich-Ebert-Stiftung Russia. 2007. (In Russ.) URL: http://www.isras.ru/analytical_report_Ident.html (accessed 18.08.2017).

Salatova L.M. Stereotypical Images of the World Crisis in Russian and American Graphical Models. Bulletin of Chelyabinsk State University. 2014. No. 10. P. 110-115 (In Russ.).

Sani I. Abdullah M. Abdullah F. Ali Z. Political Cartoons as a Vehicle of Setting Agenda: The Newspaper Example. - Asian Social Science. 2012. Vol. 8. No. 6. DOI: http://dx.doi.org/10.5539/ass.v8n6p156

Sharkov F.I. Visualization of Political Media Space. - Polis. Political Studies. 2016. No. 5. P. 97-107. (In Russ.) https://doi.org/10.17976/jpps/2016.05.08

Shifman L. Memes in Digital Culture. Cambridge, MA: MIT Press. 2014. 199 p.

Solovyov A.I. Political Communication: To the Problem of Theoretical Identification. - Polis. Political Studies. 2002. No. 3. P. 5-18. (In Russ.) https://doi.org/10.17976/jpps/2002.03.02

Sorokin P.A. Sotsiologiya revolyutsii [Sociology of Revolution]. Moscow: ROSSPEN. 2005. 704 p. (In Russ.)

Sysoev V.V. Hodite tiho, govorite tiho [Be Quiet, Speak Quiet]. Paris, New York: Tretya volna. 1983. 98 p. (In Russ.)

Temnitskii A.L. Uchebnoe Issledovanie Po Empiricheskoi Sotsiologii [Educational Study on Empirical Sociology]. Moscow: Moscow State University of International Relations. 2003. 250 p. (In Russ.)

Tsakona V. Popa D.E. Studies In Political Humour: In Between Political Critique and Public Entertainment. Amsterdam, Philadelphia: John Benjamins Publishing Company. 2011. 290 p.

Tsykalov D.Eu. The Cartoon as an Instrument of Propaganda During World War I. - Science Journal of VolSU. History. Area Studies. International Relations. 2012. Vol. 17. No. 1. P. 85-90. (In Russ.) http://dx.doi. org/10.15688/jvolsu4.2012.1.12

Vorob'eva I.V. Contradictions and Paradoxes of Political Orientations in the Life-world Structure of Russians. - Sotsiologicheskie issledovaniya. 2016. No. 1. P. 17-26 (In Russ.)

Zlatkovskii M. "Yumor Molodykh": Iz Istorii Karikatury V Rossii 1953-2000 Gody ["Humor of the Young": from the History of Russian Cartoons of 1953-2000 Years]. - Fenomenologiya Smekha. Karikatura, Parodiya, Grotesk V Sovremennoi Kul'ture. [The Phenomenology of Laughter. Cartoon, Parody and Grotesque in Modern Culture: Articles Digest]. Moscow: Rossiiskii institut kul'turologii [Russian Institute for Cultural Research]. 2002. P. 28-83. (In Russ.) 